\title{
ANALISIS JALUR FAKTOR ANGKA KEMATIAN IBU DI PROVINSI JAWA TIMUR TAHUN 2014
}

\author{
Abdi Iswahyudi Yasril ${ }^{1}$, Mahmudah ${ }^{2}$ \\ ${ }^{1}$ Sekolah Tinggi Ilmu Kesehatan Fort De Kock Bukittinggi, \\ J1. Soekarno Hatta No.11, Manggis Ganting, Mandiangin Koto Selayan, \\ Kota Bukittinggi, Sumatera Barat 26117 \\ ${ }^{2}$ Departemen Biostatistika dan Kependudukan \\ Fakultas Kesehatan Masyarakat Universitas Airlangga \\ Kampus C Mulyorejo Surabaya, Jawa Timur 60115 \\ Alamat Korespondensi: Abdi Iswahyudi Yasril \\ E-mail: iswahyudiabdi2893@gmail.com
}

\begin{abstract}
ABSTRACK
Path analysis was a statistical analysis technique which was developed from multiple regression analysis. This method was used to analyze the causal relationship that involve many variables such as maternal mortality rate (MMR). Many variables influenced the MMR but it was not easy to find the dominant variable because it will create problems multicolinearity. Therefore it used path analysis to analyze the direct and indirect effects in the incidence of MMR based on the model of causal relationship. The purpose of this study to apply path analysis on factors that affect maternal mortality rate in East Java province. This study was a non-reactive using data SUSENAS and East Java Provincial Health Profile 2014 on maternal mortality rate in all districts in East Java using path analysis. The results of path analysis showed that there was influence between the variables of women who married at age $<17$ years $(p=$ $0.045 ; \beta=0.376)$, birth attendance by non-medical $(p=0.013 ; \beta=0.475)$ and obstetric complications $(p=0.036 ; \beta$ $=0.323)$ on the incidence of MMR. Analyzed furthermore of variables woman who married at age $<17$ years $(\beta=$ $0.528)$ and birth attendance by non-medical $(\beta=0.632)$ influenced directly and indirectly to MMR. It was expected by using this path analysis health practitioners could improve their services and assistances to all pregnant women for early detection of high risk pregnancy.
\end{abstract}

Keywords : path analysis, maternal mortality rate, East Java province

\begin{abstract}
ABSTRAK
Analisis jalur merupakan suatu teknik analisis statistika yang dikembangkan dari analisis regresi berganda. Metode ini digunakan untuk menganalisis hubungan sebab akibat yang melibatkan banyak variabel seperti angka kematian ibu (AKI). Banyak variabel yang mempengaruhi AKI tetapi tidak mudah untuk menemukan variabel yang lebih dominan karena akan menimbulkan masalah multi kolinearitas. Maka daripada itu digunakan analisis jalur yang bertujuan untuk menganalisis pengaruh langsung dan tidak langsung kejadian AKI dalam model hubungan antar variabel yang bersifat kausalitas. Tujuan penelitian ini untuk melakukan penerapan analisis jalur pada faktor yang mempengaruhi AKI di Provinsi Jawa Timur tahun 2014. Penelitian ini bersifat non reaktif dengan menggunakan data sekunder SUSENAS dan Profil Kesehatan Provinsi Jawa Timur tahun 2014 tentang angka kematian ibu di seluruh kabupaten/kota di Jawa Timur menggunakan analisis jalur. Total sampling digunakan dalam pengambilan sampel. Hasil analisis jalur menunjukkan bahwa ada pengaruh antara variabel wanita yang menikah pada usia $<17$ tahun $(p=0,045 ; \beta=0,376)$, penolong persalinan oleh non medis $(p=0,013 ; \beta=0,475)$ dan komplikasi kebidanan $(p=0,036$; $\beta=0,323)$ terhadap kejadian AKI. Setelah dikaji lebih lanjut variabel wanita yang menikah pada usia $<17$ tahun $(\beta=$ $0,528)$ dan penolong persalinan oleh tenaga non medis $(\beta=0,632)$ berpengaruh secara langsung dan tidak langsung terhadap AKI. Diharapkan dengan penggunaan analisis jalur ini, tenaga kesehatan yang berwenang dapat meningkatkan pelayanan dan pendampingan kepada seluruh ibu hamil untuk mendeteksi secara dini kehamilan resiko tinggi.
\end{abstract}

Kata Kunci: analisis jalur, angka Kematian Ibu, Provinsi Jawa Timur 


\section{PENDAHULUAN}

Analisis jalur (path analysis) merupakan suatu teknik analisis statistika yang dikembangkan dari analisis regresi berganda. Teknik ini pertama kali dikembangkan oleh Sewell Wright pada tahun 1930-an. Teknik ini digunakan untuk menguji hubungan kausal antara satu variabel dengan variabel lain (Sudaryono, 2011).

Analisis jalur berguna untuk menganalisis pola hubungan antar variabel, yang digunakan untuk mengetahui pengaruh langsung dan tidak langsung dari variabel independen terhadap variabel dependen. Model yang digunakan yaitu berupa pola antar kausal dari variabel $\mathrm{X}_{1}, \mathrm{X}_{2} \ldots \mathrm{X}_{\mathrm{k}}$ terhadap Y (Riduwan, 2014).

Menurut Riduwan (2014) metode analisis jalur ada yang disebut metode trimming dan metode dekomposisi. Metode trimming adalah metode yang digunakan untuk memperbaiki suatu struktur analisis jalur dengan cara mengeluarkan variabel independen yang koefisien jalurnya tidak signifikan, sedangkan metode dekomposisi merupakan metode yang menekankan pada pengaruh yang bersifat kausalitas antar variabel.

Pada suatu penelitian analisis multivariat, peneliti sering menemukan adanya masalah hubungan dua atau lebih variabel yang disebut multikolinearitas. Analisis jalur merupakan salah satu cara untuk mengatasi masalah multikolinearitas (Sudaryono, 2011).

Permasalahan dalam bidang kesehatan sangat kompleks, banyak sekali fenomena hubungan sebab akibat yang melibatkan multivariabel. Teori dan model dalam dunia kesehatan secara umum diformulasikan menggunakan konstruk yang tidak dapat diukur secara langsung, sehingga ada variabel yang tidak teramati. Pola hubungan antar variabel pun sering kali berhubungan langsung dan tidak langsung (Eulis, 2010).

Kesehatan adalah salah satu indikator kesejahteraan penduduk dan juga merupakan indikator keberhasilan program pembangunan. Upaya peningkatan derajat kesehatan ibu dan anak, yaitu pada ibu hamil, ibu bersalin dan bayi merupakan salah satu program pembangunan kesehatan di Indonesia (Depkes RI, 2012).
Angka kematian ibu (AKI) di Indonesia masih tergolong tinggi dibandingkan negara Asean lainnya yaitu 359 kematian per 100.000 kelahiran hidup (BPS, 2012), padahal target yang ingin dicapai hingga tahun 2015 adalah 102 kematian per 100.000 kelahiran hidup (Depkes RI, 2012). Tingginya AKI dikarenakan masih rendah kesadaran perilaku hidup bersih dan sehat, serta masih rendahnya status kesehatan ibu, gizi, kualitas pelayanan ibu hamil, dan kondisi kesehatan lingkungan (Hanim, 2015).

Banyak faktor yang bisa berpengaruh terhadap AKI tetapi tidak mudah untuk menemukan faktor yang lebih berpengaruh. McCarthy \& Deborah (1992) menyatakan bahwa ada 3 faktor yang mempunyai pengaruh terhadap kematian ibu. Faktor pertama adalah determinan dekat, yaitu kehamilan dan komplikasi baik dalam kehamilan, persalinan dan nifas. Faktor yang kedua adalah determinan antara. Determinan antara adalah faktor yang mempengaruhi determinan dekat secara langsung. Determinan antara terdiri dari status kesehatan ibu, status reproduksi, akses ke pelayanan kesehatan, dan perilaku penggunaan pelayanan kesehatan. Faktor yang ketiga adalah determinan jauh. Determinan jauh mempengaruhi determinan antara yang meliputi faktor budaya dan ekonomi yaitu status wanita dalam keluarga dan masyarakat.

Menurut Fibriana (2007), faktor yang mempengaruhi AKI, yaitu faktor ibu, status reproduksi, pelayanan kesehatan, sosial ekonomi dan sosial budaya. Berdasarkan hasil penelitian Dina (2013), diketahui bahwa variabel umur pada kelompok beresiko mengalami kematian maternal dibagi atas umur muda ( $\leq 20$ tahun) dan umur tua (> 35 tahun) yang sebanyak 33 orang (34\%) responden yang merupakan kelompok beresiko kematian maternal. Hasil penelitian menunjukkan ada hubungan yang bermakna antara umur beresiko dengan kejadian kematian maternal.

Usia kurang dari 20 dan diatas 35 tahun dapat berisiko untuk terjadinya kematian ibu sebesar tiga kali. Hal ini kemungkinan disebabkan oleh penyakit yang diderita ibu saat hamil atau adanya komplikasi selama persalinan, nifas atau pertolongan persalinan oleh non kesehatan (dukun bayi) atau terlambat mencapai atau mendapatakan pertolongan medis. 
Variabel lain yang diteliti menunjukkan pengaruh terhadap kejadian maternal adalah adanya hubungan paritas dengan kejadian kematian maternal diperoleh ada sebanyak 23 orang $(65,7 \%)$ responden dengan paritas $\leq 1$ atatu $>4$ orang (beresiko) mengalami kematian maternal (Dina, 2013).

AKI di Provinsi Jawa Timur pada tahun 2014 mencapai 93,52 per 100.000 kelahiran hidup. Capaian ini telah berada di bawah target MDGs 2015102 per 100.000 kelahiran hidup tetapi masih berada diatas target RENSTRA yang ingin dicapai yaitu 80 per 100.000 kelahiran hidup (Dinkes Provinsi Jawa Timur, 2015).

Berdasarkan data, lebih dari $50 \%$ Kabupaten/Kota di Provinsi Jawa Timur memiliki AKI berada diatas angka provinsi. Angka tertinggi dimiliki Kota Surabaya yakni 39 per 100.000 kelahiran hidup, sedangkan Kota Batu dan Kota Mojokerto memiliki angka terendah yakni 1 per 100.000 kelahiran hidup (Dinkes Provinsi Jawa Timur, 2015).

Hasil Susenas Provinsi Jawa Timur tahun 2014 diketahui bahwa usia perempuan yang pernah menikah dibawah 17 tahun sebesar $27,11 \%$, pertolongan persalinan dengan tenaga non medis sebesar $6,19 \%$. Rata-rata paritas (anak lahir hidup) sebesar 1,86 (BPS Provinsi Jawa Timur, 2015). Berdasarkan Profil Kesehatan Jawa Timur tahun 2014, menunjukkan bahwa provinsi Jawa Timur pada tahun 2014 diketahui bahwa komplikasi kebidanan ditangani sebesar 91,47 \% (Dinkes Provinsi Jawa Timur, 2015).

Berdasarkan latar belakang, maka tujuan penelitian ini adalah melakukan penerapan analisis jalur pada faktor yang mempengaruhi angka kematian ibu (AKI) di Provinsi Jawa Timur tahun 2014.

\section{METODE PENELITIAN}

Penelitian ini bersifat non reaktif dengan menggunakan data sekunder yang ada di Badan Pusat Statistik, dan Dinas Kesehatan Provinsi Jawa Timur. Data yang digunakan adalah angka kematian ibu (AKI) pada tahun 2014 di setiap Kabupaten/Kota di Provinsi Jawa Timur yang terdiri dari persentase komplikasi kebidanan yang ditangani, persentase wanita yang pernah menikah dibawah usia 17 tahun, rata - rata jumlah anak yang dilahirkan hidup, dan persentase pertolongan persalinan oleh tenaga non medis.

Populasi penelitian mencakup seluruh wilayah Provinsi Jawa Timur pada tahun 2014 yang terdiri dari 38 Kabupaten/Kota dengan menggunakan Total Sampling. Instrumen penelitian yaitu mengumpulkan data sekunder berupa dokumen hasil Survei Sosial Ekonomi Nasional 2014 (BPS Provinsi Jawa Timur, 2015) dan Profil Kesehatan Provinsi Jawa Timur tahun 2014 (Dinkes Provinsi Jawa Timur, 2015). Teknik analisis data yang digunakan dalam penelitian ini adalah analisis jalur (path analaysis).

\section{HASIL PENELITIAN}

Faktor yang berpengaruh secara langsung dan tidak langsung terhadap AKI di Provinsi Jawa Timur tahun 2014 dianalisis menggunakan analisis jalur. Data yang digunakan berasal dari Profil Kesehatan Provinsi Jawa Timur (Dinkes Jatim) dan data hasil Susenas tahun 2014 (BPS).

Variabel yang diteliti meliputi: usia, paritas, pertolongan persalinan oleh tenaga non medis, dan komplikasi terhadap AKI. Untuk mendapatkan nilai dari variabel yang diteliti, setiap variabel terlebih dahulu akan dikelompokkan dalam sub struktur jalur dan setelah hasil sub struktur jalur didapatkan, maka dibuat diagram hasil sebagai rangkuman dari bagian sub struktur. Sub struktur jalur akan dibagi menjadi 2 kelompok, yaitu sub struktur jalur 1 dan 2.

Sub struktur jalur 1 terdiri dari variabel usia, paritas dan pertolongan persalinan oleh tenaga non medis terhadap komplikasi. Hasil analisis jalur sub struktur pertama dapat dilihat pada tabel 1.

\section{Usia $\left(\mathbf{X}_{1}\right)$ terhadap Komplikasi $\left(\mathbf{X}_{4}\right)$}

Dari hasil uji statistik dengan analisis jalur diperoleh $p$ value 0,020 dengan tingkat kepercayaan $95 \%$. Hal ini berarti persentase usia wanita yang menikah dibawah 17 tahun berpengaruh secara signifikan terhadap komplikasi.

Persentase usia wanita yang menikah dibawah 17 tahun memiliki koefisien jalur $(\beta)$ 
Tabel 1. Hasil Koefisien Jalur Variabel Usia, Paritas, dan Pertolongan Persalinan oleh Tenaga Non Medis terhadap Komplikasi

\begin{tabular}{ccccccc}
\hline $\begin{array}{c}\text { Pengaruh antar } \\
\text { Variabel }\end{array}$ & $\begin{array}{c}\text { Koefisien } \\
\text { Jalur }(\boldsymbol{\beta})\end{array}$ & Sig. & $\begin{array}{c}\text { Hasil } \\
\text { Pengujian }\end{array}$ & CI 95\% & $\begin{array}{c}\text { Koefisien } \\
\text { Determinan } \\
\text { Rsquare }\end{array}$ & $\begin{array}{c}\text { Koefisien } \\
\text { Variabel } \\
\text { Lain } \\
\text { (sisa) }\end{array}$ \\
\hline $\mathrm{X}_{1}$ terhadap $\mathrm{X}_{4}$ & 0,472 & 0,020 & Signifikan & $0,08-0,94$ & & \\
$\mathrm{X}_{2}$ terhadap $\mathrm{X}_{4}$ & 0,389 & 0,016 & Signifikan & $2,8-26$ & 0,332 & 0,668 \\
$\mathrm{X}_{3}$ terhadap $\mathrm{X}_{4}$ & 0,489 & 0,003 & Signifikan & $0,19-0,86$ & & \\
\hline
\end{tabular}

sebesar 0,472 terhadap persentase komplikasi. Hal ini menunjukkan apabila persentase usia wanita yang menikah dibawah 17 tahun meningkat maka diperkirakan dapat meningkatkan persentase komplikasi sebesar 0,472 .

\section{Paritas $\left(\mathbf{X}_{2}\right)$ terhadap Komplikasi $\left(\mathbf{X}_{4}\right)$}

Menurut hasil uji statistik dengan analisis jalur diperoleh $p$ value 0,016 , Ini berarti rata-rata jumlah anak yang dilahirkan hidup (paritas) berpengaruh secara signifikan terhadap persentase komplikasi.

Rata-rata jumlah anak yang dilahirkan hidup memiliki koefisien jalur $(\beta)$ sebesar 0,389 terhadap persentase komplikasi. Hal ini menunjukkan bahwa apabila rata-rata jumlah anak yang dilahirkan meningkat dan tidak dibatasi maka diperkirakan dapat meningkatkan persentase komplikasi sebesar 0,389.

\section{Pertolongan persalinan oleh tenaga non medis $\left(\mathbf{X}_{3}\right)$ terhadap komplikasi $\left(\mathbf{X}_{4}\right)$}

Hasil uji statistik dengan analisis jalur diperoleh $p$ value 0,003 , hal ini berarti persentase pertolongan persalinan oleh tenaga non medis berpengaruh secara signifikan terhadap persentase komplikasi. Persentase pertolongan persalinan oleh non medis memiliki koefisien jalur $(\beta)$ sebesar 0,489 terhadap komplikasi.

Hal ini menunjukkan bahwa apabila persentase pertolongan persalinan oleh tenaga non medis meningkat maka akan terjadi peningkatan risiko terhadap komplikasi sebesar 0,489 .

Hasil analisis jalur sub struktur kedua dapat dilihat pada tabel 2 dan tabel 3. Berdasarkan tabel 2 uji statistik dan koefisien jalur diperoleh hasil bahwa variabel usia, pertolongan persalinan oleh tenaga non medis dan komplikasi berpengaruh signifikan terhadap AKI, namun variabel paritas tidak berpengaruh secara signifikan terhadap AKI. Oleh karena itu sesuai dengan hasil 2 pada tabel 3, variabel yang signifikan akan diuji kembali dengan mengeluarkan variabel paritas yang hasil koefisien jalurnya tidak signifikan dari analisisnya. Maka dari itu akan terlihat hasil perhitungannya.

Tabel 2. Hasil 1 Koefisien Jalur Variabel Usia, Paritas, dan Pertolongan Persalinan oleh Tenaga Non Medis terhadap Komplikasi AKI

\begin{tabular}{|c|c|c|c|c|c|c|}
\hline $\begin{array}{c}\text { Pengaruh antar } \\
\text { Variabel }\end{array}$ & $\begin{array}{c}\text { Koefisien } \\
\text { Jalur ( } \beta \text { ) }\end{array}$ & Sig. & $\begin{array}{c}\text { Hasil } \\
\text { Pengujian }\end{array}$ & CI $95 \%$ & $\begin{array}{c}\text { Koefisien } \\
\text { Determinan } \\
\text { Rsquare }\end{array}$ & $\begin{array}{c}\text { Koefisien } \\
\text { Variabel } \\
\text { Lain } \\
\text { (sisa) } \\
\end{array}$ \\
\hline $\mathrm{X}_{1}$ terhadap $\mathrm{Y}$ & 0,329 & 0,044 & $\begin{array}{c}\text { Tidak } \\
\text { Signifikan }\end{array}$ & $0,01-0,82$ & \multirow{4}{*}{0,363} & \multirow{4}{*}{0,636} \\
\hline $\mathrm{X}_{2}$ terhadap $\mathrm{Y}$ & 0,103 & 0,522 & Signifikan & $10,4-20,2$ & & \\
\hline $\mathrm{X}_{3}$ terhadap $\mathrm{Y}$ & 0,335 & 0,035 & Signifikan & $0,01-0,26$ & & \\
\hline $\mathrm{X}_{4}$ terhadap Y & 0,328 & 0,039 & Signifikan & $0,02-0,81$ & & \\
\hline
\end{tabular}


Tabel 3. Hasil 2 Koefisien Jalur Variabel Usia, Paritas, dan Pertolongan Persalinan oleh Tenaga Non Medis terhadap Komplikasi AKI

\begin{tabular}{lcccccc}
\hline $\begin{array}{c}\text { Pengaruh antar } \\
\text { Variabel }\end{array}$ & $\begin{array}{c}\text { Koefisien } \\
\text { Jalur }(\boldsymbol{\beta})\end{array}$ & Sig. & $\begin{array}{c}\text { Hasil } \\
\text { Pengujian }\end{array}$ & CI 95\% & $\begin{array}{c}\text { Koefisien } \\
\text { Determinan } \\
\text { Rsquare }\end{array}$ & $\begin{array}{c}\text { Koefisien } \\
\text { Variabel } \\
\text { Lain } \\
\text { (sisa) }\end{array}$ \\
\hline $\mathrm{X}_{1}$ terhadap Y & 0,376 & 0,045 & Signifikan & $0,02-1,87$ & & \\
$\mathrm{X}_{3}$ terhadap Y & 0,475 & 0,013 & Signifikan & $0,18-1,43$ & 0,336 & 0,664 \\
$\mathrm{X}_{4}$ terhadap Y & 0,323 & 0,036 & Signifikan & $0,03-0,79$ & & \\
\hline
\end{tabular}

\section{Usia $\left(\mathbf{X}_{1}\right)$ terhadap AKI (Y)}

Menurut hasil uji statistik dengan analisis jalur pada tabel 3 diperoleh $p$ value 0,045 , artinya persentase usia wanita yang menikah dibawah 17 tahun berpengaruh terhadap AKI. Persentase usia wanita yang menikah dibawah 17 tahun memiliki koefisien jalur $(\beta)$ sebesar 0,376 terhadap angka kematian ibu. Hal ini menunjukkan bahwa apabila persentase usia wanita yang menikah dibawah 17 tahun meningkat maka diperkirakan dapat berisiko meningkatkan terjadinya angka kematian ibu sebesar 0,376.

\section{Paritas $\left(\mathbf{X}_{2}\right)$ terhadap AKI (Y)}

Hasil uji statistik dengan analisis jalur diperoleh $p$ value 0,522 , ini berarti rata-rata jumlah anak yang dilahirkan hidup tidak berpengaruh terhadap AKI.

\section{Pertolongan persalinan oleh tenaga non medis $\left(\mathbf{X}_{3}\right)$ terhadap AKI (Y)}

Dari hasil uji statistik dengan analisis jalur diperoleh $p$ value 0,013. Ini berarti bahwa penolong persalinan oleh non medis berpengaruh secara signifikan terhadap angka kematian ibu. Persentase pertolongan persalinan oleh tenaga non medis memiliki koefisien jalur $(\beta)$ sebesar 0,475 terhadap AKI. Hal ini menunjukkan bahwa apabila persentase pertolongan persalinan oleh tenaga non medis meningkat maka diperkirakan dapat meningkatkan risiko kejadian AKI sebesar 0,475 .

\section{Komplikasi $\left(\mathbf{X}_{4}\right)$ terhadap AKI (Y)}

Sesuai hasil uji statistik dengan analisis jalur diperoleh $p$ value 0,036 , pada tabel 3 . Hal ini berarti persentase komplikasi berpengaruh secara signifikan terhadap AKI.

Persentase komplikasi memiliki koefisien jalur $(\beta)$ sebesar 0,323 terhadap angka kematian ibu. Hal ini menunjukkan bahwa apabila persentase komplikasi meningkat maka diperkirakan dapat meningkatkan angka kematian ibu sebesar 0,323.

Berdasarkan hasil koefisien jalur pada tabel 1 dan tabel 2, maka dapat digambarkan secara keseluruhan pengaruh kausal antar variabel dalam bentuk diagram jalur. Jalur yang dibentuk akan memperlihatkan nilai dari masing-masing variabel. Mekanisme jalur antar variabel dapat dilihat pada gambar 1 dan gambar 2 .

Gambar 1 dan gambar 2 menunjukkan bahwa nilai signifikan dan koefisien jalur untuk variabel usia, pertolongan persalinan oleh tenaga non medis dan komplikasi berpengaruh secara langsung terhadap AKI. Sedangkan pada variabel paritas menunjukkan bahwa nilai signifikan dan koefisien jalur tidak berpengaruh langsung terhadap AKI, namun paritas secara tidak langsung berpengaruh terhadap AKI melalui komplikasi.

Berdasarkan gambar 3 dan gambar 4 didapatkan diagram jalur antar variabel yang signifikan terhadap AKI. Hasil analisis ini diperoleh dari perbaika diagram jalur pada gambar 1 dan gambar 2. 


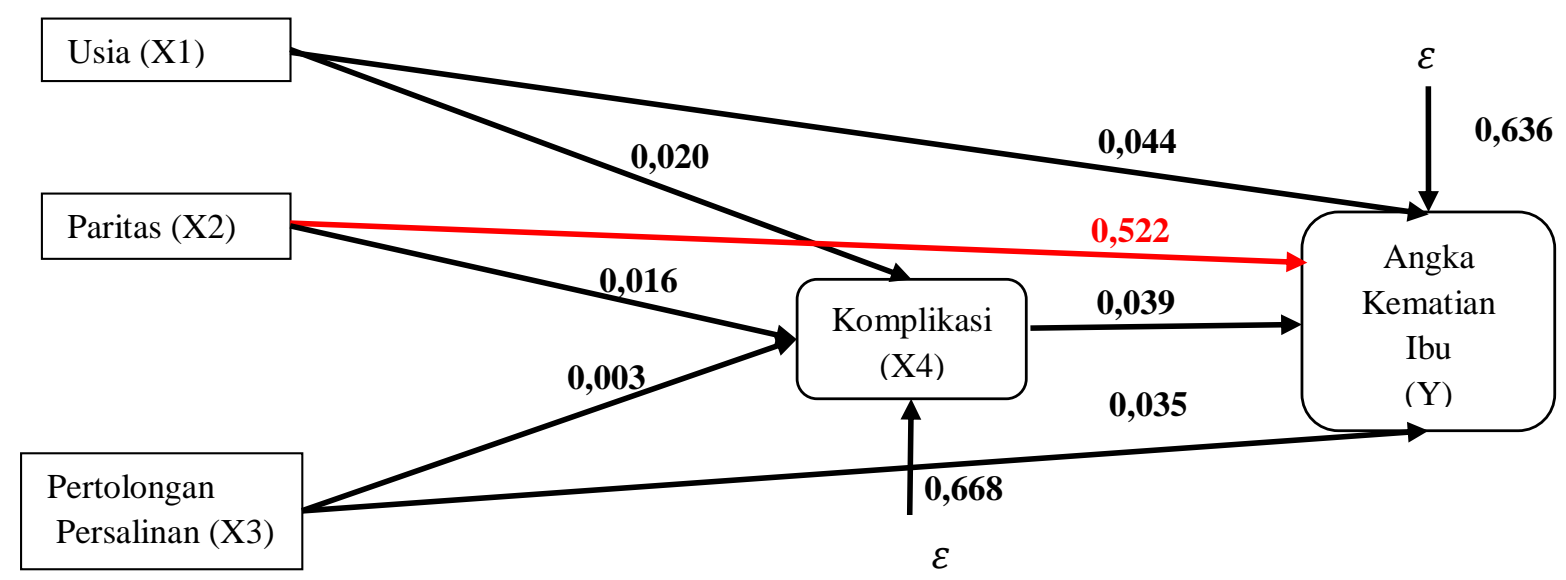

Gambar 1. Hasil Diagram Analisis Jalur dengan Nilai Signifikan Variabel Usia, Paritas, Pertolongan Persalinan oleh Tenaga Non Medis dan Komplikasi Terhadap AKI

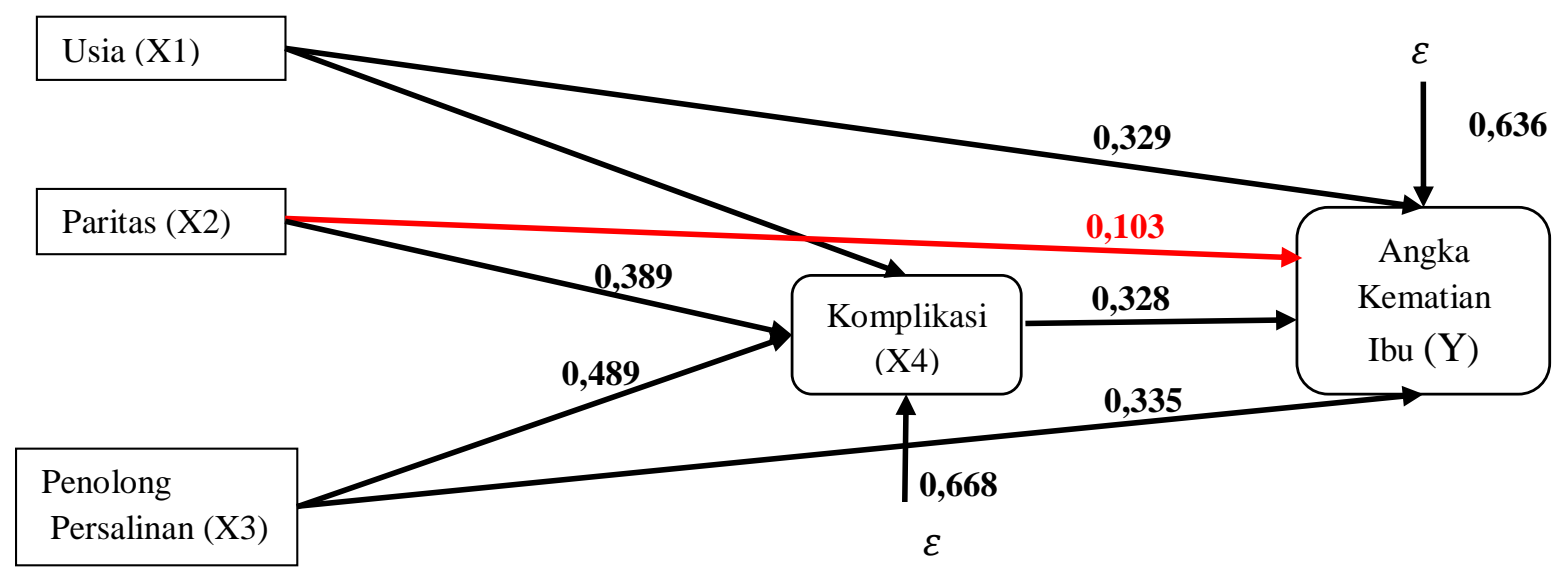

Persamaan struktur $\mathrm{Y}: \mathrm{P}_{\mathrm{yx} 4} \mathrm{X}_{4}+\mathrm{P}_{\mathrm{yx} 1} \mathrm{X}_{1}+\mathrm{P}_{\mathrm{yx} 2} \mathrm{X}_{2}+\mathrm{P}_{\mathrm{yx} 3} \mathrm{X}_{3}+\mathrm{P}_{\mathrm{y}} \varepsilon ; \mathrm{R}_{\text {square }}=0,328 \mathrm{X}_{4}+0,329 \mathrm{X}_{1}+0,103 \mathrm{X}_{2}$ $+0,335 X_{3}+0,636 \varepsilon ; 0,363$.

Gambar 2. Hasil Diagram Analisis Jalur dengan Nilai Koefisien Jalur Variabel Usia, Paritas, Pertolongan Persalinan oleh Tenaga Non Medis dan Komplikasi Terhadap AKI 


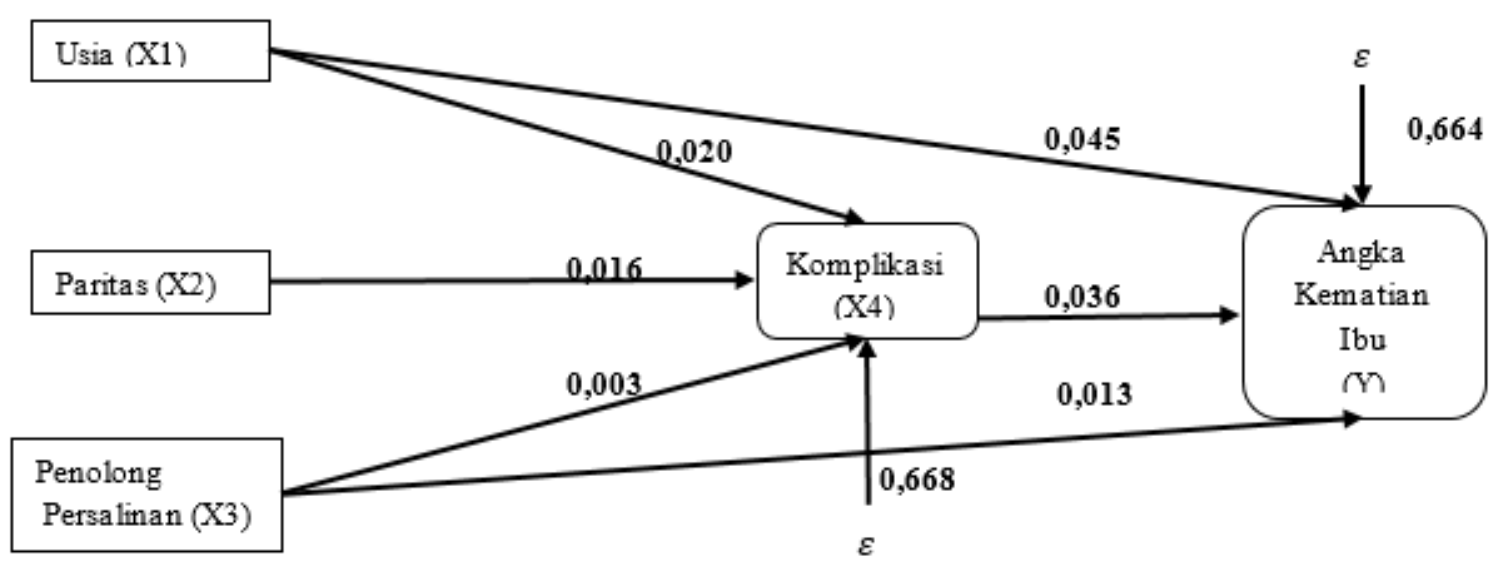

Gambar 3. Hasil Nilai Signifikan Analisis Jalur pada Variabel Usia, Pertolongan Persalinan oleh Tenaga Non Medis dan Komplikasi Terhadap AKI

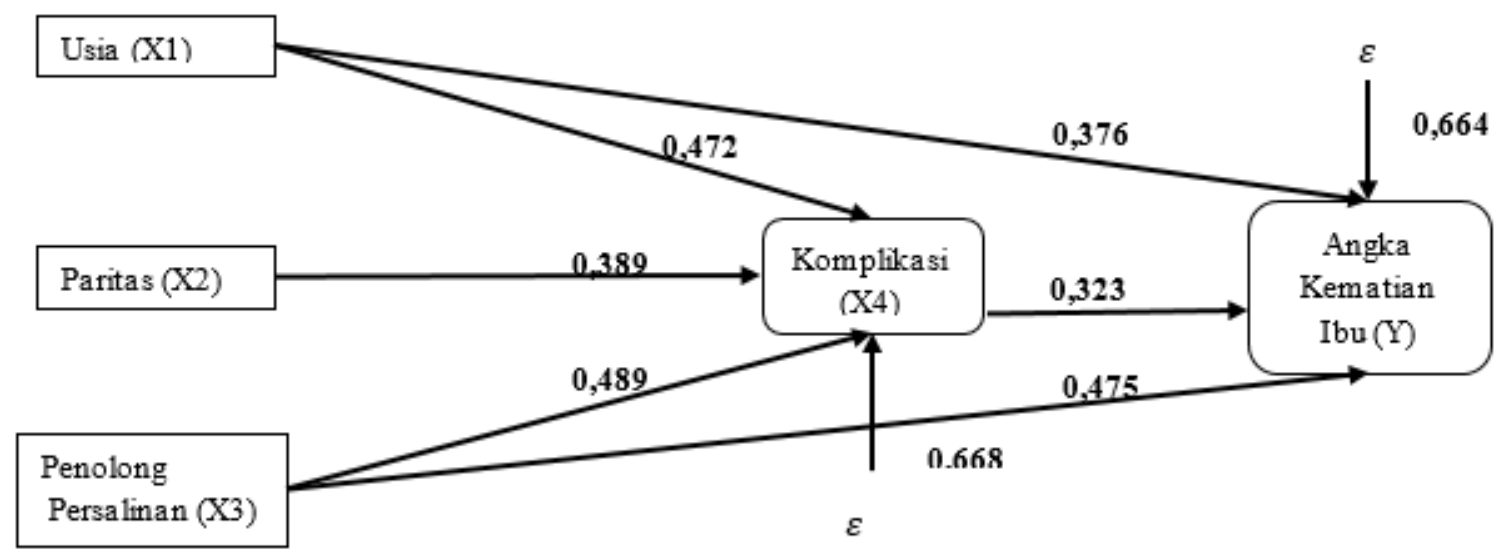

Persamaan struktur $\mathrm{Y}: \mathrm{P}_{\mathrm{yx} 4} \mathrm{X}_{4}+\mathrm{P}_{\mathrm{yx} 1} \mathrm{X}_{1}+\mathrm{P}_{\mathrm{yx} 3} \mathrm{X}_{3}+\mathrm{P}_{\mathrm{y}} \varepsilon ; \mathrm{R}_{\text {square }}=0,323 \mathrm{X}_{4}+0,376 \mathrm{X}_{1}+0,475$ $\mathrm{X}_{3}+0,664 \varepsilon ; 0,336$.

Gambar 4. Hasil Analisis dengan Nilai Koefisien Jalur pada Variabel Usia, Pertolongan Persalinan oleh Tenaga Non Medis dan Komplikasi Terhadap AKI

Pada gambar 3 dan gambar 4 diperoleh koefisien jalur dari masing - masing variabel. Variabel komplikasi berpengaruh langsung terhadap AKI, dan variabel paritas berpengaruh secara tidak langsung terhadap AKI melalui komplikasi sedangkan variabel usia dan pertolongan persalinan oleh tenaga non medis berpengaruh secara langsung terhadap AKI serta berpengaruh secara tidak langsung melalui komplikasi.

Pada tabel 4 diperoleh faktor yang dominan dari hasil diagram analisis jalur yaitu variabel usia wanita menikah dibawah 17 tahun $(\beta=$ $0,528)$ dan pertolongan persalinan oleh tenaga non medis $(\beta=0,632)$ berpengaruh secara langsung dan tidak langsung terhadap angka kematian ibu (AKI). 
Tabel 4. Rangkuman dari Koefisien Jalur Pengaruh Langsung dan Tidak Langsung, serta Pengaruh Total Usia $\left(\mathrm{X}_{1}\right)$, Paritas $\left(\mathrm{X}_{2}\right)$, Penolong Persalinan Non Medis $\left(\mathrm{X}_{3}\right)$, dan Komplikasi $\left(\mathrm{X}_{4}\right)$ terhadap AKI

\begin{tabular}{lccc}
\hline & \multicolumn{3}{c}{ Pengaruh Kausal } \\
\cline { 2 - 3 } Pengaruh Variabel & & $\begin{array}{c}\text { Tidak Langsung } \\
\text { Melalui }\end{array}$ & \multirow{2}{*}{ Total } \\
\cline { 2 - 3 } & Langsung & Komplikasi $\left(\mathbf{X}_{4}\right)$ & \\
\cline { 2 - 3 } & & 0,152 & $0,376+0,152=0,528$ \\
$\mathrm{X}_{1}$ terhadap Y & 0,376 & 0,125 & 0,125 \\
$\mathrm{X}_{2}$ terhadap Y & & 0,157 & $0,475+0,157=0,632$ \\
$\mathrm{X}_{3}$ terhadap Y & 0,475 & & 0,323 \\
$\mathrm{X}_{4}$ terhadap Y & 0,323 & & \\
\hline
\end{tabular}

\section{PEMBAHASAN}

Analisis jalur berguna untuk kasus yang mempunyai banyak variabel, selain di bidang kesehatan, analisis jalur juga bisa diterapkan pada bidang ilmu lainnya, seperti ilmu ekonomi, manajemen, psikologi, dan ilmu sosial (Tobing, 2014).

Analisis jalur merupakan suatu pengembangan dari regresi berganda, artinya regresi berganda itu merupakan bentuk khusus dari analisis jalur. Teknik ini juga dikenal sebagai model causing modeling. Analisis jalur bermanfaat untuk menguji proposisi teoritis mengenai hubungan sebab dan akibat tanpa memanipulasi beberapa variabel. Memanipulasi variabel maksudnya ialah memberikan perlakuan terhadap beberapa variabel tertentu dalam pengukurannya (Riduwan, 2014). AKI adalah indikator yang digunakan untuk menentukan derajat kesehatan masyarakat, sehingga beberapa program kesehatan banyak menitikberatkan pada upaya penurunan AKI. Berdasarkan hasil penelitian didapatkan faktor yang mempengaruhi AKI.

Usia perkawinan pertama seorang wanita memiliki risiko terhadap persalinannya. Semakin muda usia perkawinan seorang wanita, maka semakin besar risiko untuk keselamatan ibu maupun bayi (Purwanti, 2010). Hal ini terjadi karena belum matangnya rahim wanita usia muda untuk memproduksi anak atau belum siapnya mental dalam berumah tangga.

Hasil penelitian analisis jalur menunjukkan bahwa persentase wanita yang menikah pada usia dibawah 17 tahun berpengaruh langsung secara signifikan terhadap AKI dan berpengaruh secara tidak langsung melalui komplikasi dengan total koefisien jalur sebesar 0,528. Hasil ini sesuai dengan penelitian Dina (2013) yang berpendapat bahwa ibu hamil pada umur kurang dari 20 tahun mempunyai risiko untuk terjadinya kematian ibu sebesar 3,5 kali (OR = 3,5: 95\% CI).

Usia 20-35 tahun merupakan usia yang aman untuk hamil dan melahirkan, karena mereka ada dalam masa reproduksi yang sehat. Jika pada usia 14 tahun seorang wanita sudah melahirkan, maka ia akan memiliki risiko kematian 5 - 7 kali saat melahirkan. Sedangkan wanita yang melahirkan pada usia 15 - 19 tahun memiliki dua kali lipat risiko kematian saat melahirkan (BPS, 2012).

Dari hasil Susenas di Jawa Timur tahun 2014, masih terdapat sekitar $27,11 \%$ penduduk wanita usia diatas 10 tahun melakukan perkawinan pertama di usia terlalu muda. Perkawinan di usia muda masih ada saat ini, mengingat saat ini ada sekitar 0,20 persen penduduk perempuan pada kelompok usia 10-14 tahun telah berstatus pernah kawin. Padahal pada kelompok usia ini mereka mestinya ada di bangku pendidikan formal, karena masuk dalam rentang usia pendidikan dasar sembilan tahun. Selain berakibat pada rendahnya tingkat pendidikan, perkawinan pada kelompok usia muda tersebut akan menyebabkan peluang lebih besar untuk memiliki jumlah anak lebih banyak. Untuk itu perlu peningkatan akses program Keluarga Berencana (BPS Provinsi Jawa Timur, 2015).

Paritas merupakan rata-rata jumlah anak yang dilahirkan hidup oleh seorang wanita yang pernah kawin pada tahun tertentu (Prawirohardjo, 2011). Hasil analisis data menunjukkan bahwa 
Provinsi Jawa Timur pada tahun 2014 memiliki rata-rata jumlah anak yang dilahirkan hidup adalah 1,86 anak. Rata-rata terendah terdapat di Kabupaten Trenggalek sebesar 1,63 anak, sedangkan yang tertinggi terdapat di Kabupaten Sampang sebesar 2,56 anak.

Hasil analisis jalur menunjukkan bahwa ratarata jumlah anak yang dilahirkan hidup tidak berpengaruh langsung terhadap AKI namun berpengaruh secara tidak langsung melalui komplikasi dengan total koefisien jalur sebesar 0,125 . Hasil ini sesuai dengan pernyataan Fibriana (2007) yang menyatakan bahwa paritas bukanlah faktor yang mempengaruhi kematian maternal $(p=0,553)$.

Paritas kurang dari 1 dan lebih dari 4, dapat meningkatkan resiko terjadinya AKI. Ibu yang baru pertama kali hamil dan melahirkan pada usia dibawah 17 tahun secara medis maupun secara mental berisiko karena ibu belum siap, sedangkan paritas lebih dari 4 dan usia tua, juga berisiko karena secara fisik ibu mengalami kemunduran untuk menjalani kehamilan (Prawirohardjo, 2011).

Jarak kehamilan yang terlalu dekat dapat menyebabkan tingginya risiko untuk mengalami kematian maternal. Persalinan yang terlalu sering tanpa memperhatikan jarak persalinan dapat menyebabkan perdarahan postpartum, kesakitan dan kematian ibu. Jarak kehamilan yang baik dan aman adalah 2 tahun (Depkes RI, 2012).

Pertolongan persalinan bisa dijadikan salah satu indikator kesehatan, terutama hubungannya dengan kesejahteraan ibu dan pelayanan kesehatan secara umum. Namun pada kenyatannya pengaruh dukun bayi dimasyarakat sangatlah kuat. Untuk itu tenaga kesehatan telah melakukan kerjasama dengan dukun bayi daripada melepaskan mereka. Upaya yang dilakukan oleh tenaga kesehatan yaitu melatih dukun bayi dalam menggunakan material komunikasi berkaitan perawatan kehamilan dan komplikasi kebidanan yang dapat mengancam keselamatan jiwa ibu (Heny, 2015). Hasil analisis jalur menunjukkan bahwa persentase pertolongan persalinan oleh tenaga non medis berpengaruh langsung secara signifikan terhadap AKI dan berpengaruh tidak langsung melalui komplikasi dengan total koefisien jalur sebesar 0,632. Namun ada hasil lain yang diperoleh pada analisis jalur untuk variabel persalinan non medis, yaitu selain berpengaruh secara langsung, persentase peretolongan persalinan oleh tenaga non medis ternyata didapatkan pula secara tidak langsung berpengaruh terhadap AKI melalui persentase komplikasi dengan koefisien jalur total : $\beta=0,632$.

Hasil penelitian ini sama dengan pernyataan Sari (2016) yang menyatakan bahwa pertolongan persalinan oleh tenaga non medis berpengaruh secara tidak langsung terhadap AKI melalui ibu hamil risiko tinggi dengan besar pengaruh sebesar 0,005. Fibriana (2007) juga menyatakan bahwa pertolongan persalinan oleh non medis berisiko untuk terjadinya kematian ibu sebesar 3,7 kali $(\mathrm{OR}=3,7)$.

Dukun bayi adalah penolong persalinan yang belum memiliki kemampuan untuk mengenal adanya tanda - tanda komplikasi yang mungkin terjadi pada saat persalinan dan dukun bayi hanya mampu mengandalkan keterampilan yang didapat secara turun - temurun (Fibriana, 2007).

Pertolongan persalinan oleh tenaga non medis banyak menimbulkan berbagai masalah dan merupakan salah satu yang menyebabkan tingginya AKI. Hal ini dikarenakan dukun tidak mampu mengenali beberapa tanda bahaya perjalanan persalinan. Oleh karena itu perlu dilakukan pelatihan pada dukun tentang persalinan yang bersih dan aman, karena semua penolong persalinan haruslah terlebih dahulu memahami dan mempunyai pengetahuan tentang pemeriksaan kehamilan secara sungguh- sungguh (Purwanti, 2010).

Komplikasi kebidanan ditangani maksudnya adalah kesakitan pada ibu hamil, ibu bersalin, dan ibu nifas yang dengan resiko tinggi dapat mengancam jiwa ibu. Kesakitan ibu terdiri atas komplikasi ringan sampai komplikasi permanen atau menahun sesudah terjadi masa nifas. WHO memperkirakan sekitar 10\% kelahiran hidup mengalami komplikasi pascapersalinan, yaitu anemia. Jika seorang ibu telah menderita anemia maka perdarahan pascapersalinan dapat memperberat keadaan anemia dan dapat mengakibatkan kematian (Prawirohardjo, 2011).

Hasil analisis jalur menunjukkan bahwa persentase komplikasi berpengaruh langsung secara signifikan terhadap AKI. Hasil ini sesuai dengan penelitian Sarwani (2008) yang menunjukkan bahwa ada hubungan komplikasi dengan kematian ibu. Ibu yang mengalami 
komplikasi mempunyai risiko 31,9 kali lebih besar untuk terjadi kematian ibu dibandingkan yang tidak mengalami komplikasi. Penelitian Aeni (2013) menunjukkan bahwa komplikasi kehamilan memiliki pengaruh terhadap kematian ibu dengan odd rasio sebesar 12,189 (OR = 12,189; CI 95\%). Fibriana (2007) juga menyatakan bahwa ada pengaruh komplikasi kehamilan

terhadap kematian maternal $(\mathrm{p}=0,002)$. Ibu yang mengalami komplikasi kehamilan berisiko mengalami kematian ibu sebesar 147,1 kali bila dibandingkan dengan ibu yang tidak mengalami komplikasi kehamilan (OR = 147,1). Dan sejalan dengan komplikasi kehamilan Aeni (2013) juga menyatakan bahwa komplikasi persalinan mempunyai pengaruh terhadap AKI dengan OR 9,94. Ini berarti bahwa ibu yang mengalami komplikasi persalinan memiliki risiko 9,94 kali lebih besar unutk mengalami kematian ibu dibandingkan dengan ibu yang tidak mengalami komplikasi persalinan (OR $=9,94 ; 95 \%$ CI: 2,118 $-363,147)$.

Komplikasi persalinan, pada preeklamsia ringan bisa berubah menjadi preeklamsia berat sehingga akan mengakibatkan kejang. Apabila pada proses persalinan terjadi, maka akan membuat ibu mengalami kehilangan kesadaran, dan menyebabkan kematian maternal (Fibriana, 2007).

Komplikasi pada masa nifas bisa terjadi karena infeksi. Infeksi dalam masa nifas dapat menyebabkan terjadinya kematian maternal. Kematian itu terjadi karena menyebarnya kuman kedalam aliran darah sehingga dapat menyebabkan abses pada beberapa organ, seperti otak dan ginjal.

Perdarahan dalam masa nifas dapat terjadi jika ibu tidak segera mendapatkan perawatan lebih awal untuk mengendalikan perdarahan. Ibu dan bayi mengalami masalah yang harus dilakukan penanganan yang kompleks.

Pemerintah baik pusat atau daerah harus mendukung program penurunan AKI, seperti menyediakan tenaga kesehatan, tenaga penunjang kesehatan serta penyediaan sarana dan prasarana kesehatan. Bentuk dukungan seperti ini memudahkan pihak rumah sakit, puskesmas atau fasilitas kesehatan lainnya untuk membantu menangani masalah komplikasi sehingga AKI dapat diturunkan (Prawirohardjo, 2011).

\section{SIMPULAN DAN SARAN}

\section{Simpulan}

Angka kematian ibu terendah terdapat di Kota Mojokerto dan Kota Batu, yaitu sebanyak 1 kematian ibu per 100.000 kelahiran hidup, dan angka kematian ibu tertinggi terdapat di Kota Surabaya, yaitu sebesar 39 kematian ibu per 100.000 kelahiran hidup.

Hasil analisis jalur didapatkan faktor yang mempengaruhi AKI secara langsung adalah persentase komplikasi kebidanan ditangani ( $p$ value $=0,036, \beta=0,323$ ), persentase wanita yang menikah dibawah usia 17 tahun ( $p$ value $=0,045$, $\beta=0,376$ ), dan persentase pertolongan persalinan oleh tenaga non medis ( $p$ value $=0,013, \beta=$ 0,475 ) dengan nilai koefisien determinan (Rsquare) sebesar 0,336.

Hasil analisis jalur didapatkan faktor yang mempengaruhi AKI secara tidak langsung di Provinsi Jawa Timur pada tahun 2014 adalah rata-rata jumlah anak yang dilahirkan hidup ( $p$ value $=0,522, \beta=0,103$ ).

Hasil analisis jalur diperoleh faktor dominan yang berpengaruh terhadap AKI baik secara langsung maupun tidak langsung di Provinsi Jawa Timur tahun 2014 yaitu persentase wanita yang menikah dibawah usia 17 tahun dengan total koefisien jalur sebesar 0,528 dan persentase pertolongan persalinan oleh tenaga non medis sebesar 0,632 .

\section{Saran}

Kepada tenaga kesehatan yang berwenang, diharapkan dapat meningkatkan pelayanan kesehatan dan melakukan pendampingan kepada seluruh ibu hamil untuk mendeteksi secara dini kehamilan resiko tinggi sehingga angka kematian ibu bisa diturunkan.

\section{DAFTAR PUSTAKA}

Aeni, N. 2013. Faktor Risiko Kematian Ibu. Jurnal Kesehatan Masyarakat Nasional, [ejournal] 7 (10): pp. 453-459.

BPS. 2012. Survei Demografi Kesehatan Indonesia. Jakarta: Badan Pusat Statistik.

BPS Provinsi Jawa Timur. 2015. Hasil Survei Sosial Ekonomi Nasional Tahun 2014 
Provinsi Jawa Timur. Surabaya: Badan Pusat Statistik Provinsi Jawa Timur.

Depkes RI. 2012. Kajian Kematian Ibu dan Anak di Indonesia. Jakarta: Departemen Kesehatan Republik Indonesia.

Dina, H. 2013. Hubungan Empat Terlalu terhadap Kejadian Kematian Maternal di RSUD Gunung Sitoli Periode Tahun 2010 s/d 2012. Skripsi. Universitas Sumatera Utara.

Dinkes Provinsi Jawa Timur. 2015. Profil Kesehatan Provinsi Jawa Timur Tahun 2014. Surabaya: Dinas Kesehatan Provinsi Jawa Timur.

Eulis, L. 2010. Analisis Jalur dan Struktural Equation Modeling (SEM) untuk Menelaah Faktor yang Mempengaruhi Tekanan Darah di RSUD Harjono Ponorogo. Skripsi. Universitas Airlangga.

Fibriana, A. 2007. Faktor-faktor resiko yang Mempengaruhi Kematian Maternal. Tesis. Universitas Diponegoro.

Hanim, D. 2015. Modul Komunikasi, Informasi, Edukasi Kesehatan Reproduksi. Surakarta: Universitas Sebelas Maret.

Heny, N. 2015. Hubungan Tingkat Kepercayaan Ibu Hamil terhadap Kemampuan Dukun Bayi dengan Pemilihan Jenis Tenaga Penolong Persalinan di Puskesmas Bancak Kecamatan Bancak Kabupaten Semarang. Jurnal Medika Respati, [e-journal] 10 (3): pp. 1-11.

McCarthy, J., Deborah, M. 1992. A Framework for Analyzing the Determinants of Maternal
Mortality. Study in Family Planning, [ejournal] 23 (1): pp. 23-33.

Prawirohardjo, S. 2011. Ilmu kebidanan. Jakarta: PT Bina Pustaka.

Purwanti, D.D. 2010. Faktor yang Mempengaruhi Angka Kematian Bayi di Provinsi Jawa Timur Tahun 2008. Skripsi. Universitas Airlangga.

Riduwan. 2014. Cara Menggunakan dan Memaknai Path Analysis (Analisis Jalur). Bandung: CV. Alfabeta.

Sari, A.N. 2016. Analisis Jalur Faktor-Faktor yang Mempengaruhi Angka Kematian Ibu di Jawa Timur. Jurnal Matematika dan Pendidikan Matematika, [e-journal] 1 (2): pp. 119-132.

Sarwani. 2008. Faktor Sosial Budaya dalam Praktik Perawatan Kehamilan, Persalinan, dan Pasca Persalinan (Studi di Kecamatan Bangsri Kabupaten Jepara). Jurnal Promosi Kesehatan Indonesia, [e-journal] 2 (1): pp. 21-31.

Sudaryono. 2011. Aplikasi Analisis (Path Analysis) berdasarkan Penempatan Variabel dalam Penelitian. Jurnal Pendidikan dan Kebudayaan, [e-journal] 17 (4): pp. 391- 403.

Tobing, S.E.G. 2014. Aplikasi Analisis Jalur dalam Menganalisis Faktor yang Mempengaruhi Angka Indeks Pembangunan Manusia (IPM) di Kabupaten Tapanuli Utara Periode 2003-2012. Tugas Akhir. Universitas Sumatera Utara. 